\title{
Application of Aloe vera gel and olive oil coatings to enhance fruit quality and shelf- life of ber (Ziziphus mauritiana L.)
}

Javaria Sherani ${ }^{1 *}$, Ahmad Murtaza ${ }^{1}$, Sohail Kamaran ${ }^{2}$, Faheem Altaf ${ }^{3}$, Tehseen Ali Jilani ${ }^{1}$, Mateen Sajid ${ }^{1}$, Abdul Manan ${ }^{1}$ and Saqib Bashir ${ }^{4 *}$

1. Department of Horticulture, Ghazi University, Dera Ghazi Khan, Pakistan 32200, Pakistan

2. Department of Plant Breeding and Genetics, Ghazi University, Dera Ghazi Khan 32200, Pakistan

3. Horticultural Research Sub Station, Dera Ghazi Khan Pakistan 32200, Pakistan

4. Department of Soil and Environmental Sciences, Ghazi University, Dera Ghazi Khan 32200, Pakistan *Corresponding author's email: jsherani@gudgk.edu.pk

Citation

Javaria Sherani, Ahmad Murtaza, Sohail Kamaran, Faheem Altaf, Tehseen Ali Jilani, Mateen Sajid, Abdul Manan and Saqib Bashir. Application of Aloe vera gel and olive oil coatings to enhance fruit quality and shelf-life of ber (Ziziphus mauritiana L.). Pure and Applied Biology. Vol. 11, Issue 1, pp159-168.

http://dx.doi.org/10.19045/bspab.2022.110017

Received: 19/02/2021 Revised: 23/04/2021

Accepted: 05/05/2021

Online First: $21 / 05 / 2021$

\section{Abstract}

Ber (Zizyphus maritiana Lamk) is an important tropical fruit. Ber fruit is known as "fruit of poor" because of low price in the market. This work was planned to evaluate Aloe vera gel and olive oil edible coating to enhance its shelf life and minimize post-harvest losses. The treatments included were $\mathrm{T}_{1}=($ control $), \mathrm{T}_{2}=$ Olive oil $(2 \%), \mathrm{T}_{3}=$ Olive oil $(2.5 \%), \mathrm{T}_{4}=$ Olive oil $(3 \%), \mathrm{T}_{5}=$ Aloe vera gel $(2 \%), \mathrm{T}_{6}=$ Aloe vera gel $(2.5 \%)$ and $\mathrm{T}_{7}=$ Aloe vera gel $(3 \%)$. Physico-chemical parameters of fruits were analyzed and recorded $12^{\text {th }}$ day of storage. The study revealed that both olive oil and Aloe vera gel coatings were effective in maintaining quality of Ber fruit during storage period of 12 days. Minimum physiological weight loss, lesser loss in acid contents were observed in Aloe vera gel treated fruits along with maximum color retention compared to uncoated fruits. Coatings delayed ripening. Ascorbic acid loss and decay percentage were reduced by using different concentrations of olive oil and Aloe vera gel. Based on results deduced from the present study, it is concluded that application of Aloe vera gel was at par with olive oil coating but olive oil $3 \%$ and Aloe vera $3 \%$ proved best so, these coatings could be applied to enhance fruit shelf life and quality. Keywords: Coatings; Fruit quality; Physico-chemical analysis

\section{Introduction}

Ber (Zizyphus mauritiana Lamk.) is minor fruit crop of tropical and sub-tropical regions which belongs to the family Rhamnaceae. Ber is known as poor man's apple due to nutritional composition and availability at low cost. Ber fruit is very nutritious and contains amino acids, carbohydrates, phenolic compounds, flavonoids, antioxidants, ascorbic acid, vitamin $\mathrm{A}$ and minerals such as calcium, phosphorus and iron [1]. It is usually consumed fresh and sometimes processed. Ber is cultivated in Pakistan on an area of 5425 ha and gives 24435 tons' production annually. Currently, Pakistan is not exporting ber fruits due to high post-harvest losses. Much of ber production is consumed locally. However, 
rest of its production is wasted due to higher post-harvest losses in this crop [2]. Ber fruit shows very low shelf life about 2 to 4 days at ambient temperature [3]. Higher production of ethylene and higher storage temperatures are associated with low shelf life of this crop. Techniques used to enhance the shelf life of ber are packing, chemical preservatives, modified atmospheric storage and refrigeration [4]. The use of single method to increase the shelf life is not enough. Combinations of control atmosphere storage and edible coatings increase the post-harvest life of ber [5].

Synthetic and edible coatings are used to prevent fruits from deterioration [6]. However, the safe alternative to extend shelf life of fruits and vegetables is edible coating using natural biomaterials. Coatings become a physical barrier on fruit against microbial attacks, gas exchange, solute migration towards cuticle and water loss. Edible coatings are helpful in delaying the loss of volatile compounds, delayed changes in textural properties, delay in loss of soluble material of fruit due to reduced respiration rate [7-9]. The main advantage of edible coating over synthetic coating is that it can be consumed along with food product [10]. Edible coating is found helpful to reduce browning and moisture loss and also retained the flavor of sliced apple. It can be used for coating of almond, walnut and bakery products [11-13].

Aloe vera gel and olive oil based edible coatings having antifungal characteristics are used on fruits and vegetables for enhancing post-harvest life [14]. Aloe vera gel found to be a novel coating agent with good antibacterial properties $[15,16]$. It is helpful in reducing the development of both gram positive and gram-negative bacteria. Aloe vera gel exhibited good antibacterial activity against some food borne pathogenic microorganisms such as Bacillus cereus, Salmonella typhimurium, Escherichia coli and Klebsialla pneumonia [17]. Aloe vera gel and olive oil coatings (alone or in combination with other compounds) are used to increase the shelf life of arctic snow [18], apple slices [19], sweet cherry [20], papaya fruits [21] and table grape [22]. Lot of studies have proven the effectiveness of control atmospheric storage technology and edible coatings in enhancing the shelf life on other important major fruits. On the other hand, effectiveness of edible coating to enhance the shelf life of ber is not yet proven. Therefore, the current study was designed to assess the use of aloe vera gel and olive oil coatings on the extension of postharvest shelf life and retain the keeping quality of Ber fruit.

\section{Materials and Methods}

Sample collection

Fruit samples of Ber cv. Suffan were collected from research area (Airport campus) of Ghazi University, Dera Ghazi Khan, Punjab, Pakistan $\left(30.0489^{\circ} \mathrm{N}\right.$, $70.6455^{\circ}$ E) during 2019 fruiting season. Harvested fruits were, uniform in size, shape and colors. Harvested fruit samples were also free from diseases, blemishes, damages and fungal attacks. Fruit samples were transferred in coolers with ice packs to Horticultural research sub-station Dera Ghazi Khan. Ber fruits were grouped according to physical appearance to have even distribution. Fruits were washed and soaked to loosen the dust and grits stick to the surface.

\section{Treatment details}

Experiment was comprised of one ber variety (Suffan), seven treatments $(\mathrm{T} 1=(\mathrm{control}), \mathrm{T} 2$ $=$ Olive oil $(2 \%), \mathrm{T} 3=$ Olive oil $(2.5 \%)$, T4=Olive oil (3\%), T5= Aloe vera gel $(2 \%)$, T6=Aloe vera gel $(2.5 \%)$ and $\mathrm{T} 7=$ Aloe vera gel $(3 \%)$ replicated thrice, and 50 fruits were treated per replication. Three levels $(2,2.5$ and $3 \%$ ) of Olive oil coatings made by mixing 2, 2.5 and $3 \%$ olive oil with $100 \mathrm{ml}$ of water. Aloe vera gel was also used in three levels $(2,2.5$ and $3 \%)$ and concentrations were made by mixing $2 \mathrm{ml}, 2.5 \mathrm{ml}$ and $3 \mathrm{ml}$ 
Aloe vera gel with $100 \mathrm{ml}$ water respectively. All the concentrations of olive oil and Aloe vera gel solutions were put in oven for mild heating, stirred and cooled in air [23]. Storage conditions of all fruits were at room temperature $\left(30 \pm 3^{\circ} \mathrm{C}\right)$. Physico-chemical parameters and visual observations were carried out after $4^{\text {th }}, 8^{\text {th }}$ and $12^{\text {th }}$ day of the treatment.

\section{Preparation and application of edible coatings}

Aloe vera gel was removed from leaves and homogenized in blender. Impurities and fibers were separated by filtration process. For the purpose Whatman filter No. 100 was used. The Aloe vera gel was pasteurized at $70^{\circ} \mathrm{C}$ for the period of $45 \mathrm{~min}$. The gel was cooled immediately at room temperature. $\mathrm{pH}$ was regulated at 4 by adding citric acid. For the preparation of olive oil coating, extra virgin oive oil was taken from market and simply applied after making different concentrations. All fruit samples were dipped in different concentrations of Aloe vera and olive oil edible coatings for $10 \mathrm{~min}$. This procedure was repeated twice to increase the efficiency of coatings. After dipping all fruits were kept for 2 min to drain out extra coatings left on fruits. The treated ber fruits were kept at $30 \pm 2^{\circ} \mathrm{C}$ for a period of 12 days. Initial weights were taken immediately after application of treatments. Data regarding different parameters was taken after0, 4, 8 and 12 days of interval.

\section{Physical analysis of coated and non-coated fruits: \\ Weight loss (\%)}

The coated fruits were kept at ambient temperatures and weighed every 4 days' interval to measure weight loss (\%) during storage. Weight loss (\%) was measured by the given equation.

Weight loss $(\%)=$ $\frac{\text { Initial weight-final weight }}{\text { Initial weight }} \times 100$

\section{Fruit color}

The fruit color was measured by Chromameter (Konica Minotla, model no. B8751681). The fruit samples were loaded on instrument and readings were noted $\left(\mathrm{L}^{1}, \mathrm{~L}^{2}\right.$, $\left.a^{1}, a^{2}, b^{1}, b^{2}\right)$. The average, $\left(L^{*}, a^{*}, b^{*}\right)$ was calculated as given by Chroma and hue.

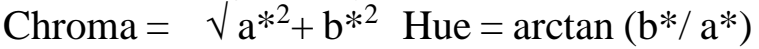

Fruit Volume $\left(\mathrm{cm}^{3}\right)$

Fruit volume of ber was determined by displacement method as described by [24]. Data was taken after 4 days interval and average was calculated.

\section{Chemical analysis of coated fruits}

TSS of fruit was taken by the digital refractor-meter (ATAGO PAL-1). $\mathrm{pH}$ of fruit was measured by the digital $\mathrm{pH}$ meter (Model of $\mathrm{pH}$ meter).

\section{Ascorbic Acid Content}

Ascorbic acid contents were assessed by following methods described by [25].

\section{Titratable acidity}

Titratable acidity was taken by the procedure described by [26]. Ten milliliters of juice were taken in $100 \mathrm{ml}$ conical flask. The samples were diluted by adding $50 \mathrm{ml}$ purified water. After that samples were titrated against $0.1 \mathrm{~N}$. $\mathrm{NaOH}$ using 2-3 drops of phenolphthalein as an indicator till pink color end point. Following formula was used to determine acidity.

$$
\text { T.A }(\%)=\frac{0.1 \mathrm{~N} \mathrm{NaOH} \text { used } \times 0.0064 \times 100}{\text { ml of juice taken for titration }}
$$

\section{Statistical analysis}

Data were subjected to analysis of variance technique as outlined by [27] and means and standard deviation were calculated for each variable.

\section{Results and Discussion \\ Fruit weight loss (\%)}

Significant variations were depicted by all treatments for weight loss (Fig. 1). Weight was declined with the increase in storage period. Uncoated fruits showed maximum weight loss whereas minimum loss in weight was depicted by fruits treated with Aloe vera 
gel and olive oil respectively. Weight loss from the fruit is mostly related with the evapotranspiration from the fruit skin hence, untreated fruits showed maximum loss in weight while the coatings prevented evaporative losses by acting as cuticle layer on fruit surface. Evaporative losses are directly linked with tissue water pressure and osmotic pressure of the surroundings along with temperature [28, 29]. Edible coatings provided waxiness to fruit surface, reduced evaporative losses by blocking gaseous exchange, reducing solute movement and delayed shelf life. Similar results were produced in guava fruit coatings [30].

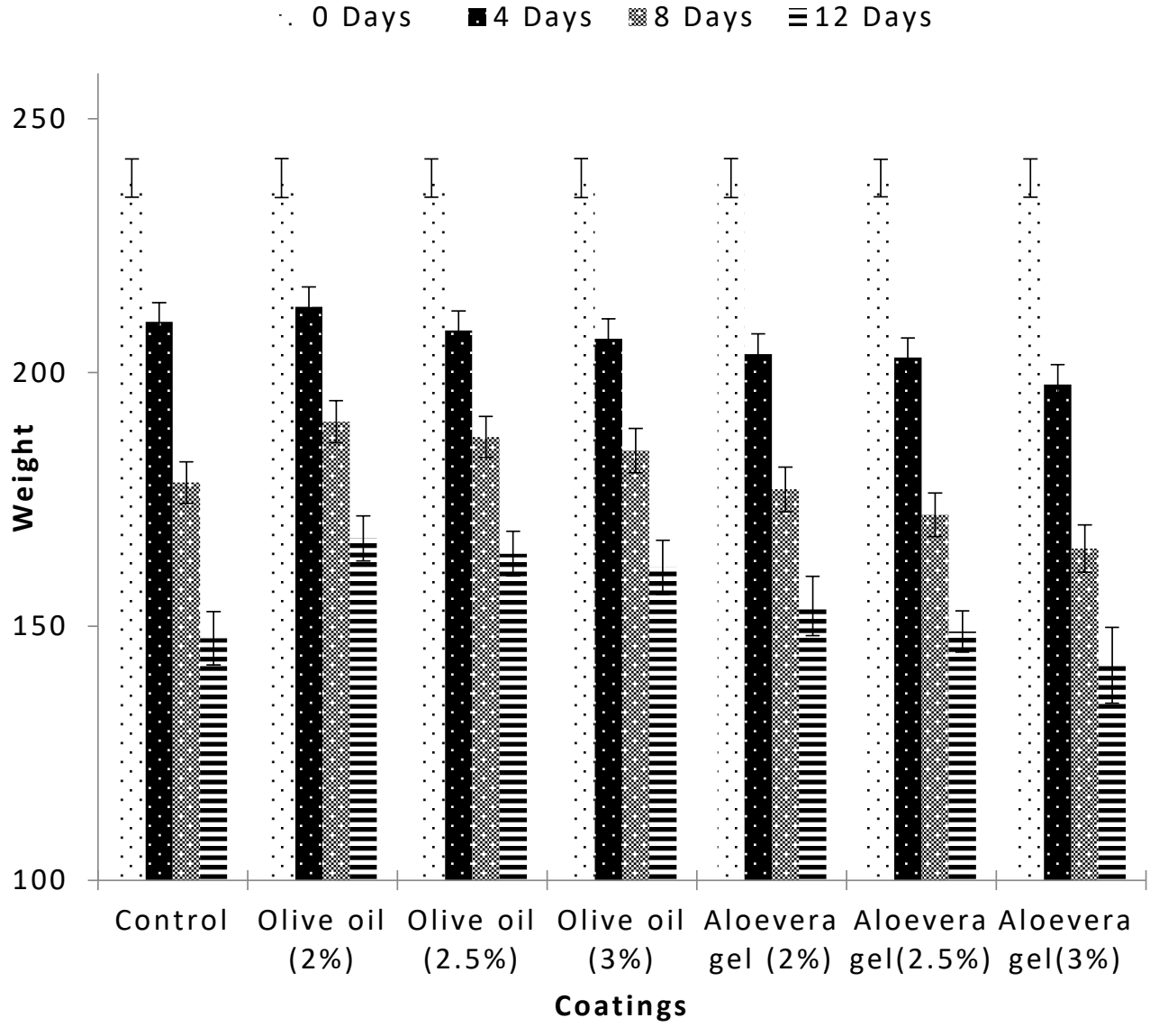

Figure 1. Fruit weight loss as affected by different concentrations of edible coatings and storage intervals

Volume $\left(\mathrm{cm}^{3}\right)$

A decline in fruit volume was observed in the all treatments as the storage period advanced. The (Fig. 2). Due to enhanced post-harvest physiological loss, volume reduced in uncoated treatments at higher speed compared with coated treatments in the order of T3 and T2. Fruit size is mainly related to respiration and the evaporation of moisture through the skin. The rate of water loss depends on the slope of the water pressure between the fruit tissues, the ambient atmosphere, and the storage temperature [28]. The main mechanism for the loss of volume of fresh fruits and vegetables is compression of the vapor in cellular compartments, while respiration also causes a decrease in volume. The reduction in 
volume may be due to these coatings as a semi-permeable barrier against oxygen, carbon dioxide, and flow of moisture and solute, thus falling respiration, water loss, and rate of oxidation reaction [30].

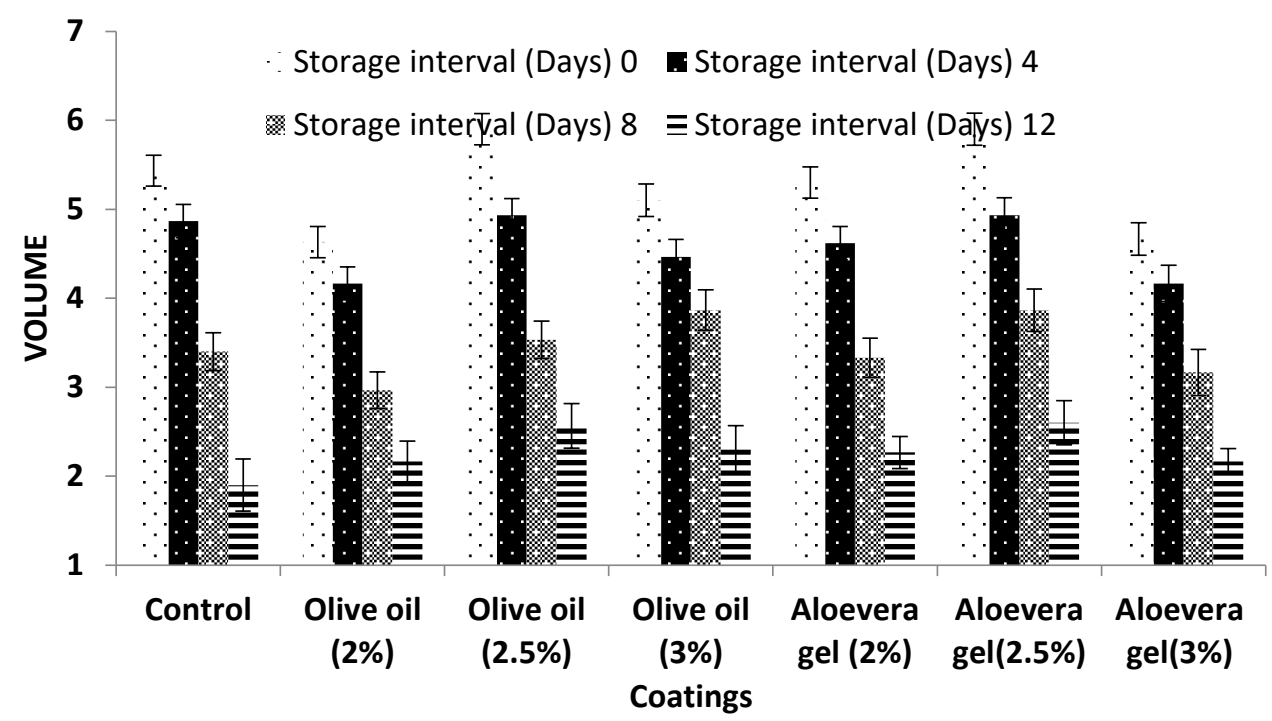

Figure 2. Fruit volume as affected by different concentrations of edible coatings and storage intervals

\section{Color}

Data regarding fruit color showed significant differences among all edible coatings (Table 1). Yellowish green (YGG150B) color was observed at the time of harvesting that turned to brown (BG200D) in T1 (untreated); grayish brown (GBG199C) in T2 (Olive coated) and yellow green (YGG145B) in T3 (Aloe Vera coated). Change in color could be attributed to speedy senescence and it affects consumer choice. As the fruit is detached from the plant, chlorophyll starts to decline. Edible coatings reduce loss of chlorophyll, reduced production of xanthophyll and delay ripening. It might be due to increased $\mathrm{CO}_{2}$ concentration and decreased $\mathrm{O}_{2}$ levels by not directly exposing to environment, which decreased ethylene biosynthesis hence, delayed ripening. Present findings were like the findings of [31].

\section{pH value}

Data regarding $\mathrm{pH}$ showed non-significant differences among edible coatings (Fig. 3).
Statistically non-significant differences were observed within treated fruits while smaller differences were found to be present among treatments that increased at same order predicting very limited role of coatings. $\mathrm{pH}$ noted at harvesting was 5.15 while 5.53 at the completion of storage $\left(12^{\text {th }}\right.$ day). Overall, it was observed that coated fruits depicted low $\mathrm{pH}$ values compared with non-coated that may be related to reduced metabolic and respiratory activities in coated ones hence, reduced utilization of organic acids [31].

Titratable acidity (\%)

Data regarding TA showed significant differences among all edible coatings during different storage periods (Fig. 4). Control treatment showed highest TA (11.37) at 0 days of storage. TA reduced as storage period increased which was 3.92 at $15^{\text {th }}$ day. However, the reduction in TA was lowest in case of coated fruit samples. Aloe vera gel treated (T3) showed minimum fall in the titratable acidity (11.48 to 7.21 ) followed by 
T2 (11.64 to 6.37). Titratable acidity in T2 and T3 was at par at $10^{\text {th }}$ and 15 th day of storage. Uncoated fruits showed a gradual decline in the TA during storage period that may be attributed to fast respiratory and metabolic activities taking place in uncoated while a steady and slow decrease in coated one is credited to coatings that reduced metabolic as well as respiratory activities. Srinivasa et al. [32], also suggested similar logic to defend findings. They pointed out reduced conversion of organic acids to sugars due to delayed metabolic activities covered by coatings. Literature on titratable acidity showed that coated and uncoated fruits had non-significant variability over storage time. However, the results of the current study indicate that the acidity values of the control fruits were significantly lesser equated to those found in coated fruits and are contradictory to Vyas et al. [33] whereas in line with Debeaufort [34]. Edible coatings act as protective layer on fruit skin and reduce respiration rate that may delay ripening and enhance shelf life of fruit [35].

Table 1 Fruit color as affected by different concentrations of edible coatings and storage intervals

\begin{tabular}{|c|c|c|c|c|}
\hline $\mathbf{L}^{*}$ & \multicolumn{4}{|c|}{ Storage interval (Days) } \\
\hline & 0 & 4 & 8 & 12 \\
\hline Control & 65.79 & 62.421 & 46.558 & 37.462 \\
\hline Olive oil $(2 \%)$ & 66.226 & 58.347 & 45.559 & 35.18 \\
\hline Olive oil $(2.5 \%)$ & 66.572 & 57.772 & 45.768 & 34.995 \\
\hline Olive oil (3\%) & 66.489 & 48.942 & 45.918 & 36.33 \\
\hline Aloe vera gel $(2 \%)$ & 66.2 & 47.951 & 44.953 & 34.927 \\
\hline Aloe vera gel $(2.5 \%)$ & 65.686 & 52.099 & 45.146 & 38.139 \\
\hline Aloe vera gel $(3 \%)$ & 65.69 & 54.926 & 44.279 & 35.14 \\
\hline \multirow[t]{2}{*}{$\mathbf{a}^{*}$} & \multicolumn{3}{|c|}{ Storage interval (Days) } & \\
\hline & 0 & 4 & 8 & 12 \\
\hline Control & -14.387 & 1.842 & 8.542 & 15.105 \\
\hline Olive oil $(2 \%)$ & -13.6 & 0.867 & 8.709 & 16.409 \\
\hline Olive oil $(2.5 \%)$ & -14.496 & -0.588 & 8.663 & 14.83 \\
\hline Olive oil $(3 \%)$ & -14.045 & 6.922 & 10.002 & 15.225 \\
\hline Aloe vera gel $(2 \%)$ & -14.221 & 11.842 & 11.499 & 15.937 \\
\hline Aloe vera gel $(2.5 \%)$ & -13.885 & 7.173 & 8.957 & 14.509 \\
\hline Aloe vera gel( $3 \%)$ & -14.301 & 6.248 & 12.177 & 15.423 \\
\hline \multirow[t]{2}{*}{$\mathbf{b}^{*}$} & \multicolumn{4}{|c|}{ Storage interval (Days) } \\
\hline & 0 & 4 & 8 & 12 \\
\hline Control & 45.427 & 50.966 & 28.091 & 20.471 \\
\hline Olive oil (2\%) & 44.958 & 41.647 & 27.136 & 19.537 \\
\hline Olive oil $(2.5 \%)$ & 46.034 & 41.587 & 25.267 & 16.116 \\
\hline Olive oil (3\%) & 45.797 & 36.039 & 25.063 & 21.73 \\
\hline Aloe vera gel $(2 \%)$ & 45.411 & 41.004 & 26.173 & 17.214 \\
\hline Aloe vera gel $(2.5 \%)$ & 45.396 & 36.574 & 26.676 & 22.65 \\
\hline Aloe vera gel $(3 \%)$ & 45.532 & 41.045 & 25.803 & 19.746 \\
\hline
\end{tabular}




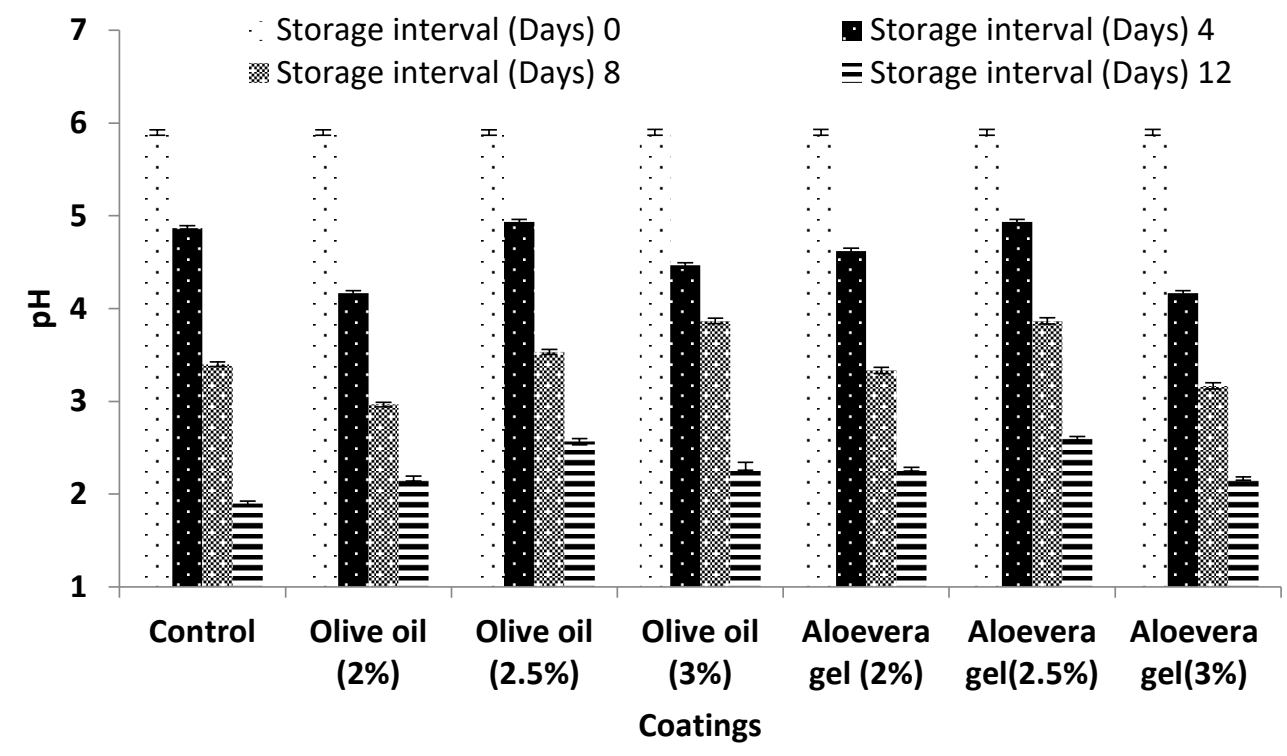

Figure 3. pH as affected by different concentrations of edible coatings and storage intervals

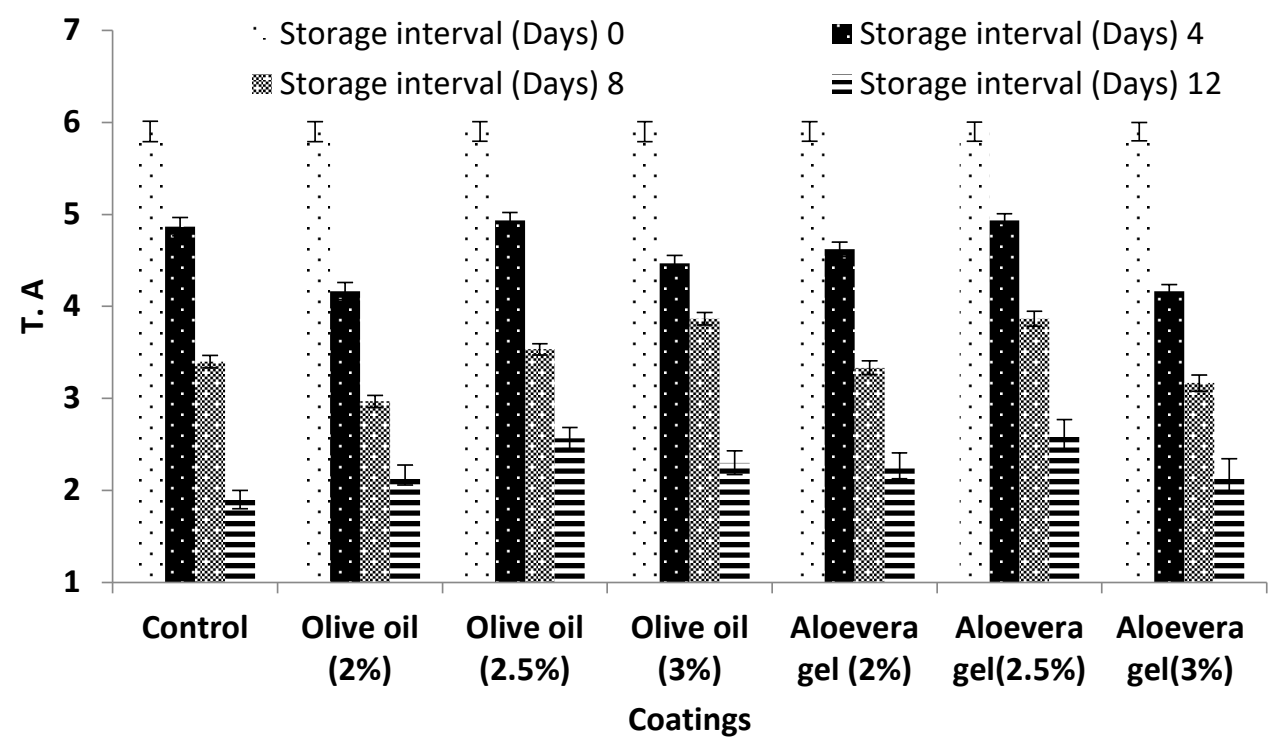

Figure 4. Titratable Acidity as affected by different concentrations of edible coatings and storage intervals

\section{Total soluble solids (mg/100gm)}

Data about TSS showed significant differences among all coated and non-coated fruits (Fig. 5). Uncoated fruits showed a huge decline of total soluble solids from o days to final storage that ranged from 13.08 at 0 day to 3.8 at $12^{\text {th }}$ day of storage. Almost similar pattern of TSS decline was also depicted by
T2 and T3. In hot arid environment most of the cultivars show good level of TSS and the changes in the value of TSS could be ascribed due seasonal/climatic differences in the area and mostly dry weather favors higher TSS in most of the cultivars [36]. Current work is supported by the findings of Togrul et al. [37] who claimed that coatings reduce 
spontaneous oxidation of the fruit by blocking direct contact to atmosphere. Present investigations concluded that Vit-C content reduces over storage period due to oxidation reactions and activity of phenol oxidase and ascorbate oxidase enzymes. The findings results are supported by the arguments of [36].

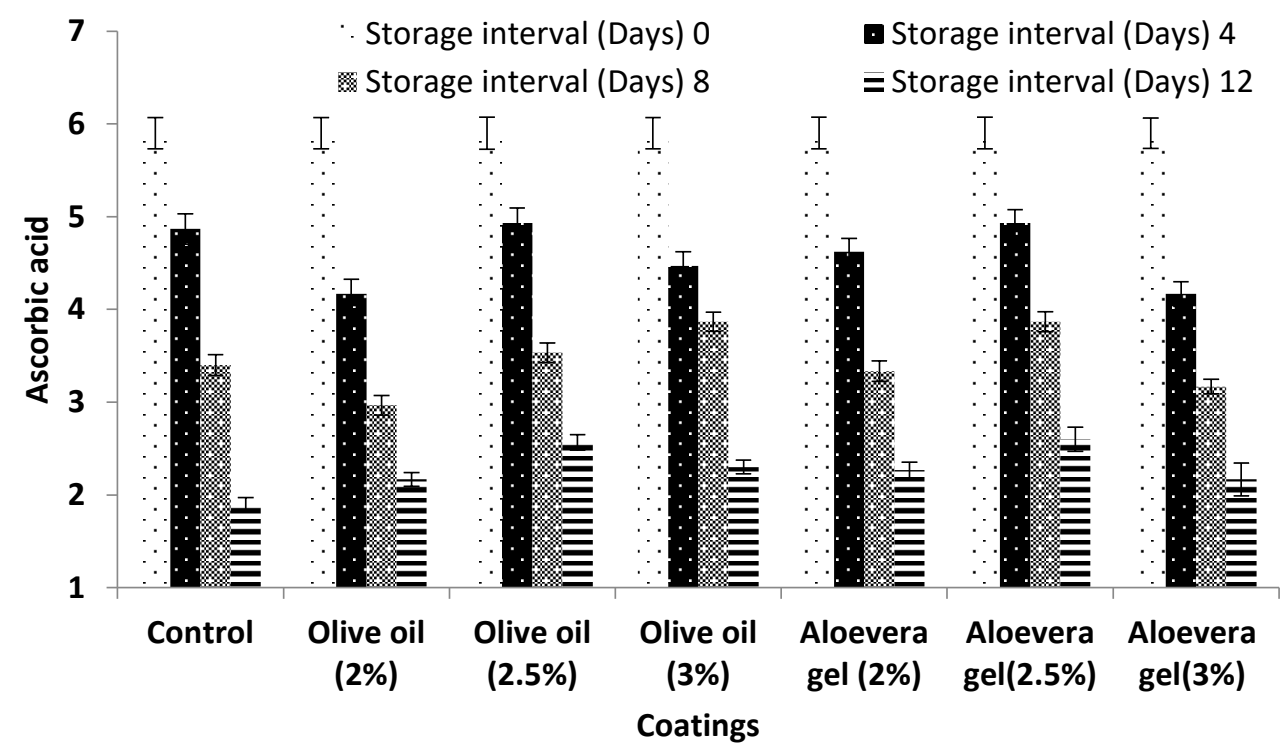

Figure 5. Ascorbic acid contents as affected by different concentrations of edible coatings and storage intervals

\section{Conclusion}

Based on results, it is concluded that Aloe vera gel and olive oil coatings are environment friendly methods of enhancing shelf life of Ber. It may be concluded that Aloe vera gel used as edible coating retained Ber fruit quality for a storage time of at least 15 days after which it begins to decline. Aloe vera gel coating blocked the direct access of fruit skin to the atmosphere and reduced enzymatic activities that enhanced shelf life as well as economic value of fruit. It was found that Olive oil coating was also an effective measure to retain fruit for 12 days after picking.

\section{Authors' contributions}

Conceived and designed the experiments: J Sherani \& A Murtaza, Performed the experiments: J Sherani, A Murtaza \& S Kamaran, Analyzed the data: S Bashir, Contributed materials/ analysis/ tools: F
Altaf, TA Jilani \& M Sajid, Wrote the paper: J Sherani \& A Manan.

\section{References}

1. Choi SH, Ahn JB, Kozukue N, Levin CE \& Friedman M (2011). Distribution of free amino acids, flavonoids, total phenolics, and antioxidative activities of jujube (Ziziphus jujuba) fruits and seeds harvested from plants grown in Korea. $J$ Agric Food Chem 59(12): 6594-6604.

2. Meena HR, Kingsly ARP \& Jain RK (2009). Effect of post-harvest treatments on shelf life of ber fruits. Indian $J$ Hortic 66(1): 58-61.

3. Pareek S, Kitinoja L, Kaushik RA \& Paliwal R (2009). Postharvest physiology and storage of ber. Stewart Postharvest Rev 5(5): 1-10.

4. Zhang D \& PC Quantick (1997). Effects of chitosan coating on enzymatic browning and decay during postharvest 
storage of litchi (Litchi chinensis Sonn.) fruit. Postharvest Biol Tec 12: 195-202.

5. Baldwin EA, Burns JK, Kazokas W, Brecht J. K, Hagenmaier RD, Bender RJ \& Pesis E (1999). Effect of two edible coatings with different permeability characteristics on mango (Mangifera indica L.) ripening during storage. Postharvest Biol Tech 17(3): 215-226.

6. Debeaufort F, Quezada-Gallo JA \& Voilley A (1998). Edible films and coatings: tomorrow's packagings: a review. Crit Rev Food Sci 38(4): 299313.

7. Pascall MA \& Lin SJ (2013). The application of edible polymeric films and coatings in the food industry. Food Processing \& Technol.

8. Park HJ, Bunn JM, Vergano PJ, \& Testin RF (1994). Gas permeation and thickness of the sucrose polyesters, semperfreshtm coatings on apples 1. J Food Proc Preserv 18(5): 349-358.

9. Lachman L, Lieberman HA \& Kanig J (1986). The Theory and Practice of Industrial Pharmacy, Lea and Febiger. Philadelphia, USA.

10. Lowe E, Hamilton W, Morgan A, Watters GG, \& Durkee E (1963). Continuous raisin coater. Food Technol 17(11): 1447.

11. Kulkarni AP, Policegoudra RS \& Aradhya SM (2007). Chemical composition and antioxidant activity of sapota (Achras sapota Linn.) fruit. $J$ Food Biochem 31(3): 399-414.

12. McHugh, TH, \& Senesi E (2000). Apple wraps: A novel method to improve the quality and extend the shelf life of freshcut apples. J Food Sci 65(3): 480-485.

13. Miers JC, Swenson HA, Schultz TH, \& Owens HS (1953). Pectinate and pectate coatings. 1. general requirements and procedures. Food Technol 7(6): 229-231.

14. Watters GG, \& Brekke JE (1961). Stabilized raisins for dry cereal products. Food Technol 15(5): 236.
15. Kumar S \& Bhatnagar T (2014). Studies to enhance the shelf life of fruits using Aloe vera based herbal coating: A Review, Noida Int. Uni., Greater Noida, and $U P$.

16. Ni Y, Turner D, Yates KÁ \& Tizard I (2004). Isolation and characterization of structural components of Aloe vera L. leaf pulp. Inter Immunopharmacol 4(14): 1745-1755.

17. Valverde JM, Valero D, MartínezRomero D, Guillén F, Castillo S, \& Serrano M (2005). Novel edible coating based on Aloe vera gel to maintain table grape quality and safety. J Agric Food Chem 53(20): 7807-7813.

18. Habeeb F, Shakir E, Bradbury F, Cameron P, Taravati MR, Drummond AJ \& Ferro VA (2007). Screening methods used to determine the anti-microbial properties of Aloe vera inner gel. Methods 42(4): 315-320.

19. Ronald M, Shelton MAJ \& Usaf MC (1991). Aloe vera: its chemical and therapeutic properties. Int $J$ Dermatol 30(10): 679-3.

20. Moore ED \& BH MacAnalley (1995). A drink containing mucilaginous polysaccharides and its preparation. US Patent 5: 443- 830.

21. Ahmed MJ, Singh Z \& Khan AS (2009). Postharvest Aloe vera gel-coating modulates fruit ripening and quality of 'Arctic Snow'nectarine kept in ambient and cold storage. Inter J Food Sci Technol 44(5): 1024-1033.

22. Chauhan OP, Raju PS, Singh A \& Bawa AS (2011). Shellac and aloe-gel-based surface coatings for maintaining keeping quality of apple slices. Food Chem 126(3): 961-966.

23. Yaman Ö \& Bayoindirl L (2002). Effects of an edible coating and cold storage on shelf-life and quality of cherries. $L W T$ Food Sci Technol 35(2): 146-150. 
24. Kumari S, Bhat DJ, Wali VK, Bakshi P \& Jasrotia A (2015). Physico-chemical studies of different ber (Zizyphus mauritiana Lamk.) germplasm under rainfed conditions of Jammu. The Bioscan 10(3): 1427-1430.

25. Ruck JA (1969). Chemical methods for analysis of fruit and vegetable products. SP 50, Summerland Research Station, Department of Agriculture, Canada.

26. Hortwitz, W., 1960. Official and tentative methods of analysis: Association of the Official Agriculture Chemist. Washington, D.C. 314-320.

27. Steel RGD, Torrie JH and Dickey DA (1997). Principles and Procedures of Statistics. A Biometrical Approach, 3rd Ed.. McGraw Hill Book Co., New York p.172-177.

28. Hernandez-Munoz P, Almenar E, Del Valle V, Velez D, \& Gavara R (2008). Effect of chitosan coating combined with postharvest calcium treatment on strawberry (Fragariax ananassa) quality during refrigerated storage. Food Chem 110(2): 428-435.

29. Yaman Ö \& Bayoundırl L (2002). Effects of an edible coating and cold storage on shelf-life and quality of cherries. $L W T$ Food Sci Technol 35(2): 146-150.

30. Baldwin EA, Burns JK, Kazokas W, Brecht JK, Hagenmaier RD, Bender RJ \& Pesis E (1999). Effect of two edible coatings with different permeability characteristics on mango (Mangifera indica L.) ripening during storage. Postharvest Biol Technol 17(3): 215-226.

31. Baraiya NS, Gol NB \& Rao TR (2012). Influence of polysaccharide-based edible coatings on the shelf life and nutritional quality of tomato fruit. Food 6(1): 22-27.

32. Srinivasa P, Baskaran R, Ramesh M, Prashanth KH \& Tharanathan R (2002). Storage studies of mango packed using biodegradable chitosan film. Eur Food Res Technol 215(6): 504-508.

33. Vyas PB, Gol NB \& Rao TR (2014). Postharvest quality maintenance of papaya fruit using polysaccharide-based edible coatings. Inter J Fruit Sci 14(1): 81-94.

34. Debeaufort F, Quezada-Gallo JA \& Voilley A (1998). Edible films and coatings: tomorrow's packagings: a review. Crit Rev Food Sci 38(4): 299313.

35. Yaman Ö \& Bayoundırl L (2002). Effects of an edible coating and cold storage on shelf-life and quality of cherries. LWTFood Sci Technol 35(2): 146-150.

36. Salunkhe DK, Bolin HR \& Reddy NR (1991). Storage, processing, and nutritional quality of fruits and vegetables. Volume I. Fresh fruits and vegetables (No. Ed. 2). CRC press.

37. Toğrul H \& Arslan N (2004). Carboxymethyl cellulose from sugar beet pulp cellulose as a hydrophilic polymer in coating of mandarin. J Food Eng 62(3): 271-279. 